The Sustainable City XIII 343

\title{
INJECTING RESIDENTIAL INDUSTRIAL NEIGHBOURHOODS AND PLOTTING BUILT-UP AREAS EXPOSED TO INDUSTRIAL AIR POLLUTANTS IN THE ARAB REPUBLIC OF EGYPT
}

\author{
NOUR EL DIN MAHMOUD, ALI F. BAKR \& AMIRA A. FATHI \\ Alexandria University, Egypt
}

\begin{abstract}
The aim of this study is to develop a strategy for predicting the highest quality areas, in terms of their non-exposure to industrial air emissions. This is achieved through listing the built-up areas next to the industrial zones concerned. Illustrating the parameters of air pollution emissions from industrial activities in the region by the air modeling technique, and integrating data and information obtained using geographical signature programs in order to obtain an informational map that can be used in analyzing the data for the future planning of housing in close proximity to industrial areas. This study was conducted on an area of $49 \mathrm{~km}^{2}$, Abu Qir Bay, east ofp the city of Alexandria, Egypt. The study showed that the safe areas of exposure to nitrogen oxides represent $8 \%$ of the study sample area $\left(49 \mathrm{~km}^{2}\right) .3 .5 \%$ represents the largest safe area located in the north-west of the industrial zone, $1.6 \%$ of the safe areas is located in the southern industrial zone towards the prevailing wind, and, finally, the ratio of built-up areas facing industrial emissions was revealed at $2.5 \%$ of the entire study area in the southern industrial zone. It is concluded that, by using the simulated gaseous emissions of industrial facilities and integrating it with geo-analytical maps of the built-up satellite-explored areas, a strategy for predicting the safe areas could be applied. The study recommends that residential urban planning decisions in industrial zones should be obtained through periodically monitoring the emissions. The researcher recommends the use of the results of this study as a guide, using (RS) satellites to detect and map built-up areas near industrial facilities, air-modelling techniques to predict the hazardous zones of the industry, and (GIS) to layer the information digitally, in order to take precise future urban planning decisions.

Keywords: residential industrial complex, hazard distances, $N O_{X}$ emission rates, petrochemical industries buffer zones, planning residential industrial neighborhoods, remote sensing built-up regions, NDVI reclassification, fertilizers industry, air modelling, industrial safe zones.
\end{abstract}

\section{INTRODUCTION}

The country's economic future is highly dependent on industrial investment. Large industrial areas represent a magnetic urban pole attracting urbanization, which presents a risk of exposure to emissions from energy extraction, and steam generation for manufacturing. The general strategies for industrial investment, in the Arab Republic of Egypt, have raised industrial growth rates to $10.7 \%$ in 2018 . More than 30 million $\mathrm{m}^{2}$ of land have been provided for the establishment of various industries since 2016. Half of the industrial settlements, are in the Greater Cairo Governorate area, reaching around 28,000 settlements.

According to the Egyptian law on Protection of the Environment No. 4/1994, issued by Prime Ministerial Decree No. 338 of 1995, the competent administrative authority (depending on the kind of the establishment) granting the license to an industrial firm, shall assess the environmental impact of the establishment for which the license is requested [1].

The industries in the region rely on fossil fuels that consume more than $60 \%$ of the total energy input. The major problem in this research is the lack of previous studies within the fields of, residential industrial neighborhood planning, and detection of the most exposed 
built up areas to industrial gaseous emissions. Whereas the share of industrial pollution in the region, is not very well documented [2].

The consumption of fossil fuels in some industries usually reaches large proportions. It is shown in pulp and paper industry by $81 \%$, chemicals $42 \%$, oil refining $23 \%$ [3]. It sometimes represents $85 \%$ of production costs for some industries, for example fertilizer industry. However, data published in 2007, by the Organization for Economic Co-operation and Development (OECD), shows that global emissions of greenhouse gases will increase by $50 \%$ by the year 2050 [4], mainly as a result of increased demand for energy, and the economic growth in large countries with emerging economies. Although natural gas is one of the cleanest fuels [5], the concentration of air pollutants resulting from its burning process, are dangerous if they exceed global standards. These emissions mainly consist of $\mathrm{CO}_{2}, \mathrm{NO}_{\mathrm{X}}$, small amounts of $\mathrm{SO}_{2}$, and $\mathrm{CO}$ [6]. Nitrogen oxides account for 3.3\% of total pollutants from manufacturing, and $\mathrm{CO}_{2}$ accounts for $17.7 \%$ of the total industrial pollutants. $\mathrm{NO}_{\mathrm{x}}$ emissions could be reduced by $80 \%$, by using modern manufacturing technology, but the cost of units to reduce the emissions is very high.

The Geographic Information System (GIS) is a computer-based information system for capturing, storing, inspecting, and submitting models of terrestrial sites. GIS can show many types of data on a single map. In this research, GIS is used to match pollution maps, generated by pollutant dispersion modelling platforms, to different built-up areas that are in proximity to plant emissions. Remote sensing methods based on the use of image data, which are obtained by cameras, scanners, or radar from Landsat satellite imagery, are used to detect areas built in the research environment. To monitor long-term land coverage, and land use change, Landsat data is crucial. Remotely sensed data has become increasingly available in digital form, allowing for their computer-assisted interpretation and processing. In 2013, Landsat 8 was launched with two sensors; the Operational Land Imager (OLI), and the Thermal Infrared Sensor (TIRS). Images consist of nine spectral bands with a spatial resolution of $30 \mathrm{~m}$ for bands 1 to 7 and 9 [7].

Lo found that a computer-assisted method of analysis of Landsat data, permits the extraction of more detailed urban land-use information, but at an accuracy of only $69 \%$ [8]. The aim of this paper is to develop a strategy to assist urban planners, and architects, to plan residential complexes near industrial regions, and to forecast the most industrial emission areas, in order to locate new construction sites. Therefore, by using spatial information, the decision-making process is transformed to a more clear, visualized proposal.

\subsection{Research location}

The study area covers about $49 \mathrm{~km}^{2}$ in the city of Alexandria, Northern Egypt. A city that experienced a 2.8\% urban expansion from 1999 up until 2013 [9]. Coordinates of the study area are as follows: latitude $31^{\circ} 14^{\prime} 57.86^{\prime} \mathrm{N}$, longitude $30^{\circ} 3^{\prime} 58.20$ "E, bordered by the Mediterranean Sea from North (see Fig. 1). The research sample includes different industrial activities, where fertilizer factories occupy half the area of the industrial complex, which is $4 \mathrm{~km}^{2}$. Abu Qir Fertilizers Company is the largest in the industrial complex of fertilizer production, spanning $825 \mathrm{~m}^{2}$. Alexandria Fertilizer Company, constructed in the year 1990, on an area of $121.836 \mathrm{~m}^{2}$ [10], and a paper production company, Rackta, on an area of $900 \mathrm{~m}^{2}$. 


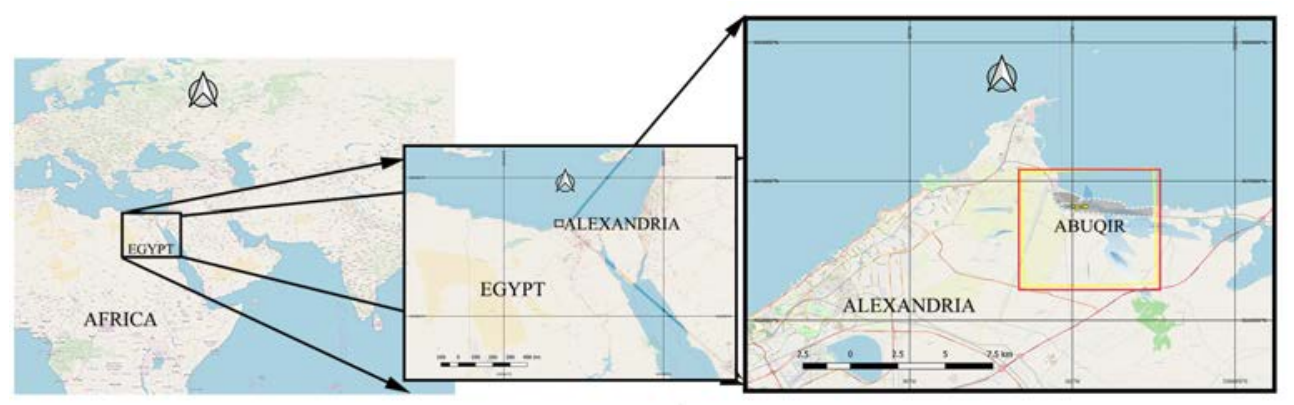

Figure 1: Research location.

\section{RESEARCH METHODOLOGY}

The study focused on tracking the parameters of $\mathrm{NO}_{\mathrm{X}}$ pollutants in the selected industrial area, as a model for implementing the proposed strategy. In addition, applying the methodology of gathering information on other industrial emissions in future studies to guide the decisions, and development of future urban planning projects in industrial contexts. The dominant industrial activity in the study area is the fertilizers industry, where $97 \%$ of nitrogen fertilizers are derived from ammonia [11]. The methodology is based on the following:

- Follow-up of high-concentration emission source of air pollutants, using gaseous dispersion tracking programs.

- Compile and analyze data and compare it to some similar local and global standards.

- Apply the developed strategy, to determine the quantity and quality of non-exposed regions in the research, with gas dispersion techniques and integrating them with the geo-analytical maps of the built-up, satellite-explored areas.

\subsection{Gaseous dispersion}

Pollutant dispersion modelling is created by feeding the industrial utilities-design standards (if available) in to the Aermod platform, Which is the EPA's preferred regulatory tool for modelling pollutant dispersion, developed by the Organizational Models Improvement Committee of the American Meteorological Society (AMS)/Environmental protection agency (EPA) [12]. It records the movement of emitted gases, identifies and measures the concentration of pollutants, acquiring the sources of emissions from industrial units, and introduces emission coefficients for deduction of flue gas.

\subsubsection{Pollutants emission rates}

Approximate emission rates of air pollutants are estimated by applying emission factors based on production quantities, and the ratios for standard industrial natural gas consumption. The emission factor for nitrogen oxides in ammonia plants is estimated at $2.7+23 \% \mathrm{~g} / \mathrm{kg}$ of ammonia [13], whereas the emission factor calculated by the material balance reaches 4.38 , $5.95 \mathrm{~g} / \mathrm{kg} \mathrm{Nh}_{3}$ [14]. Estimating the $\mathrm{NO}_{\mathrm{X}}$ emission rates for industrial large wall fired boilers, generated by using the standard percentages of natural gas burnt in ammonia plants, and applying the AP-42 Compilation of Air Emissions Factors [15]. In most of ammonia plants, an average of $65 \%$ to $75 \%$ of the natural gas is used as chemical feedstock, while $25 \%$ to $35 \%$ is used as fuel for the radiant heat section burnt in primary reformer for generating heat 
and steam production [16]. The percentage of fuel consumed in boilers, can be calculated by Using the global standards of the best available techniques in ammonia production. Whereas, Natural gas used in a typical ammonia plant, using the steam reforming process, ranges between 26.6 to $33.6 \mathrm{MMBtu} / \mathrm{ton}$, which is approximately 19-21 MMBtu/ton of ammonia used as feedstock. 6.8-8.5 MMBtu/ton is fuel in the primary reformer, and most of the remaining fuel, 0.5-4.0 MMBtu/ton, powers auxiliary boilers, which generates $7.4 \%$ of the total consumption of natural gas in the fertilizer industry. While the standard fuel consumption for industrial boilers reaches $80 \%$ of natural gas used for steam generation in pulp production facilities [17], Natural gas use can account for up to $85 \%$ of operating costs for ammonia industries. Ammonia is manufactured by steam reforming process in the primary reformer and the temperatures of the process reaches more than $900^{\circ} \mathrm{C}$ [18].

\subsubsection{Plant inventory and locations of $\mathrm{NO}_{\mathrm{X}}$ pollutant}

By tracking the emission points of air pollutants from different industries, guided by typical emission levels in natural gas-based steam repair plants [18], the industrial units emitting $\mathrm{NO}_{\mathrm{X}}$ pollutant have been mapped on a digital map for the study location (as illustrated in Fig. 2). The standard height of stacks in primary reformers for ammonia processing, ranges from $35 \mathrm{~m}$ to $50 \mathrm{~m}$, whereas flow gas standard speeds from chimneys reaches $185,000 \mathrm{NM}^{3}$. The internal diameter of the stacks ranges up to $2 \mathrm{~m}$. Gas discharge temperature in the combustion nozzles reaches $120^{\circ} \mathrm{C}$ [19], and in industrial boilers, the combustion gas temperature reaches $150^{\circ} \mathrm{C}$ to $180^{\circ} \mathrm{C}$ [20]. The amount of ammonia produced in the region of study is about 8 million tons per year for Abukir Fertilizers Company, and about 1925 tons per day at Alexandria Fertilizer Company [21]. The total consumption of industrial natural gas in the study area for the ammonia plants of AFC is approximately 700 million $\mathrm{m}^{\mathrm{s}}$ per year [22], as for Rackta company the consumption reaches 36 million $\mathrm{m}^{3}$ per year [23].

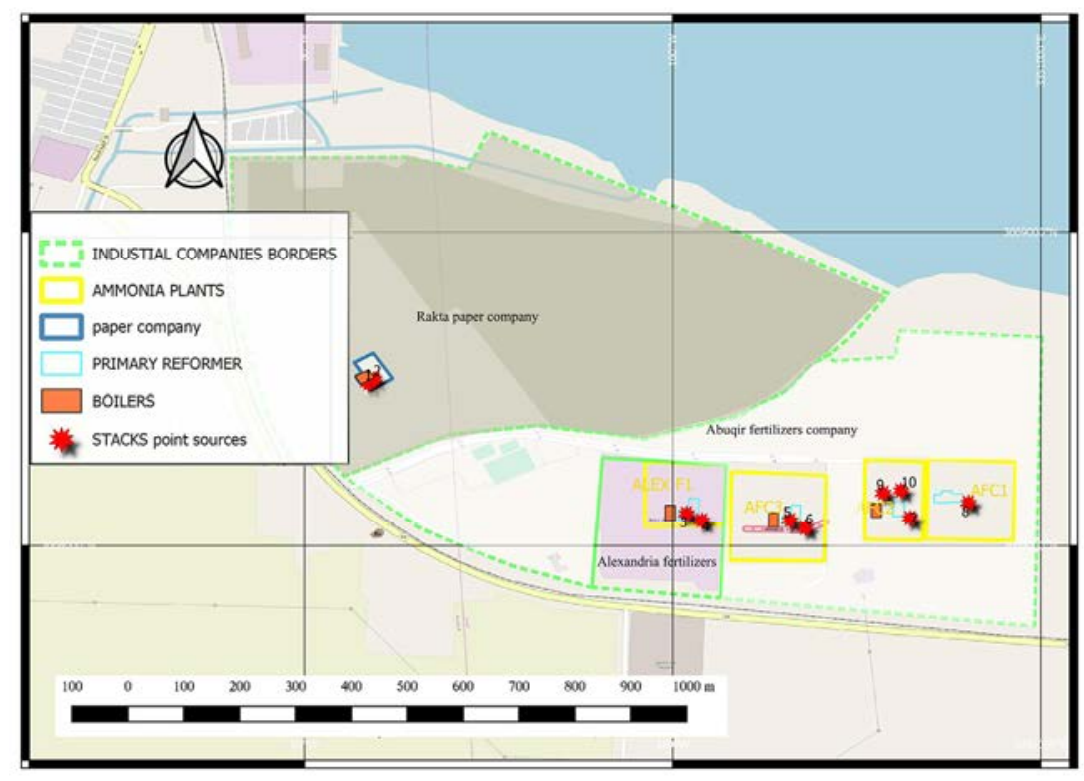

Figure 2: Locations of boilers and primary reformers in the study zone of Abukir industrial area (latitude $31^{\circ} 14^{\prime} 57.86^{\prime \prime} \mathrm{N}$, longitude $30^{\circ} 3^{\prime} 58.20^{\prime \prime} \mathrm{E}$ ). 


\subsection{Built-up zones}

A Landsat 8 image from the 8th of August 2018, on path 177, row 38, was used in this research. The data was provided as level L1T data captured under clear atmospheric conditions (cloud coverage $=0.01 \%$ ) in the dry season. The image is in UTM projection (zone $36 \mathrm{~N}$ ) and was retrieved from the United States Geological Survey (USGS), Earth Explorer website. Spectral indices are a good approach to differentiate land cover types [24]. The normal deviation of vegetation index NDVI of satellite imagery of sanitary plants is used in different formulas to generate studies for the separation of vegetation regions on digital geographical maps [25]. Previously, Matthias and Martin applied spectral NDVI to map an uncertain region in an urban area of Germany [26]. An appropriate threshold of values from the output of the equation, can be used for mapping built-up and non-built-up areas. As NDVI can be used to characterize the evolution and expansion of built-up land [27].

A reclassification process of Ndvi value is used to segregate the built up regions on the open GIS platform QGIS, which is a free and open-source cross-platform desktop geographic information system (GIS) application that supports viewing, editing, and analysis of geospatial data [28], NDVI is calculated in Landsat 8 after the formula (band 5-Band 4)/(band $5+$ band 4). For most satellites, NDVI, are calculated from eqn (1):

$$
\text { NDVI }=(\text { Pnir- } \rho d) /(\text { Pnir }+\rho d)
$$

where Pnir reflects the wavelength range near infrared and $\rho d$ is the reflection of the red wavelength range. While the bands used are band 4 with the wavelength ranges of $0.636-0.673 \mu \mathrm{m}$ and the range 5 for the wavelength $0.851-0.879$ [29].

\subsection{Pollution maps and built-up spatial relation}

Environmental impact assessment (EIA) process is the systematic examination of consequences of a proposed project, aiming to prevent, reduce or mitigate negative impacts on the environment, natural resources, health and social elements as well as capitalize on positive impacts of the project [30].

The Egyptian EIA system was designed with the support of the Danish International Development Agency (DANIDA), where it is summarized in the annex along with the corresponding features of the World Bank's Environmental Assessment policy OP 4.01 and the European Union's EIA Council Directive 97/11/EC [31].

The results of pollutant contours are generated on the Aermod platform with EU standards. They are then exported to shape file extensions, to be projected on the generated built-up regions on the QGIS platform. The results are stored in a digital geographical map, that can be visualized and analyzed. The main aim for the study is to spatially analyze the built-up regions exposed to industrial gaseous emissions.

Global standard limits of the EU air quality levels are regulated by the COUNCIL DIRECTIVE 1999/30/EC of 22 April 1999, for exposure of 1 hour to nitrogen oxides pollutants the concentrations should not exceed $200 \mu \mathrm{g} / \mathrm{m}^{3}$ [32]. Whereas, the legislation as reported by the Egyptian Environmental Affairs Agency (EEAA), based on support from Danish International Development Assistance (DANIDA), and a national network of air contamination in the Republic of Egypt, has reached the maximum allowable exposure standard to $\mathrm{NO}_{\mathrm{X}}$ at $400 \mu \mathrm{g} / \mathrm{m}^{3}$ (shown in Table 1), As The EEAA has the power to set criteria and conditions, monitor compliance and to take procedures against violators of these criteria and conditions. The EEAA must be notified of any expansions or renewals to the existing facility or any work, which might result in an adverse impact on the environment. 
Table 1: Global standards of $\mathrm{NO}_{\mathrm{x}}$ pollutant emissions. (Source: Ke, W.K, 2006.)

\begin{tabular}{lccc}
\hline & \multicolumn{3}{c}{$\mathrm{NO}_{\mathrm{X}}$ concentrations $\left(\mu \mathrm{g} / \mathrm{m}^{3}\right)$} \\
\cline { 2 - 4 } $\begin{array}{l}\text { Direct exposure } \\
\text { period }\left(\mu \mathrm{g} / \mathrm{m}^{3}\right)\end{array}$ & $\begin{array}{c}\text { Egyptian air } \\
\text { quality standards } \\
(\text { Law 4/1994) }\end{array}$ & $\begin{array}{c}\text { Application (world } \\
\text { bank general } \\
\text { environment } \\
\text { guidelines, PPAH) }\end{array}$ & $\begin{array}{c}\text { Eu standards for air } \\
\text { quality (directive } \\
1999 / 30 / \mathrm{EC})\end{array}$ \\
\hline 1 hour period & 400 & - & 200 \\
24 hour period & 150 & 150 & 125 \\
Annual period & & 300 & 40 \\
At the facility fence & & & \\
\hline
\end{tabular}

\section{RESULTS AND DISCUSSION}

\section{1 $\mathrm{NO}_{\mathrm{X}}$ pollutant contours}

Nitrogen oxide emission rates, for primary reformers, in ammonia plants, ranged from the application of nitrogen oxides emission factor, to $(37 \mathrm{~g} / \mathrm{s})$ and $(41 \mathrm{~g} / \mathrm{s})$. The emission factors for boilers in fertilizer plants were estimated at $(10.5 \mathrm{~g} / \mathrm{s}),(28.5 \mathrm{~g} / \mathrm{s})(\mathrm{AFC} 3)$. The emission rates for boilers at Rakta Paper Manufacturing $(14 \mathrm{~g} / \mathrm{s})$ were calculated based on standard fuel consumption rates (see Table 2), as the EEAA and EPAP [33], funding the projects to convert the company boilers systems to work on natural gas instead of using mazut fuel. Calculations were also applied using the material equilibrium emission factor for the second case, resulting in nitrogen oxides emission rates for primary reformers ranging from $68 \mathrm{~g} / \mathrm{s}$ to $75 \mathrm{~g} / \mathrm{s}$.

Table 2: Emission rate of $\mathrm{NO}_{\mathrm{X}}$ estimated in the industrial study area.

\begin{tabular}{|c|c|c|c|c|c|}
\hline \multirow{3}{*}{ Emission rates $(\mathrm{g} / \mathrm{s})$} & \multicolumn{5}{|c|}{ Industrial complex plants } \\
\hline & \multicolumn{3}{|c|}{$\begin{array}{l}\text { Abukir Fertilizers } \\
\text { Company }\end{array}$} & \multirow{2}{*}{$\begin{array}{c}\text { Alexandria } \\
\text { Fertilizers } \\
\text { ALEX FERT }\end{array}$} & \multirow{2}{*}{$\begin{array}{c}\text { Rackta } \\
\text { paper } \\
\text { Boilers } \\
4 \text { and } 5 \\
\end{array}$} \\
\hline & $\mathrm{AFC1}$ & AFC2 & AFC3 & & \\
\hline $\begin{array}{l}\text { Case 1: (Normal ranges in } \\
\text { Primary reformers ) }\end{array}$ & 36.94 & 33.59 & 40.30 & 40.30 & - \\
\hline $\begin{array}{l}\text { Case 2: (Material balance } \\
\text { standards for Primary reformers) }\end{array}$ & 68 & 62 & 74.37 & 74.37 & - \\
\hline Boilers & - & 10.5 & 28.5 & 28.5 & 14.04 \\
\hline
\end{tabular}

3.2 Mapping built-up areas using the NDVI index

The NDVI values in Fig. 3, were calculated from eqn (1), where high threshold ranges represent healthy vegetation (NDVI values $>0.24$, represented in dark green), while lower threshold and negative values represent water surfaces. In order to determine the optimum value, to segregate built-up from non-built-up areas, a test was conducted on the number of built-up pixels by selecting values of 0 to 0.24 . The output is illustrated in Fig. 4 , where the pixels in red show built-up areas, and the dark and green tones represent other land covers. Fig. 5(a) shows hand digitized vector areas, tracing the built-up zones on QGIS open GIS platform, on a google map background for the study area, where a boundary of $7 \mathrm{~km}$ height 
by $7 \mathrm{~km}$ width has been chosen as a limit for the tracing process surrounding a $4 \mathrm{~km}^{2}$ industrial complex. Fig. 5(b) illustrates the extracted vector layers for built-up areas on QGIS open platform by reclassifying NDVI values. Using the tracing method for built-up areas on QGIS platform, resulted in an area of $7644390.3433 \mathrm{~m}^{2}\left(7.644 \mathrm{~km}^{2}\right)$. Near values extracted from the automated reclassification method of NDVI index for Landsat 8 images, results in the mapping of a built-up area $7648902.763 \mathrm{~m}^{2}\left(7.648 \mathrm{~km}^{2}\right)$ (Fig. 5(a) and 5(b)), which identify that the method of extraction is clear and practical.

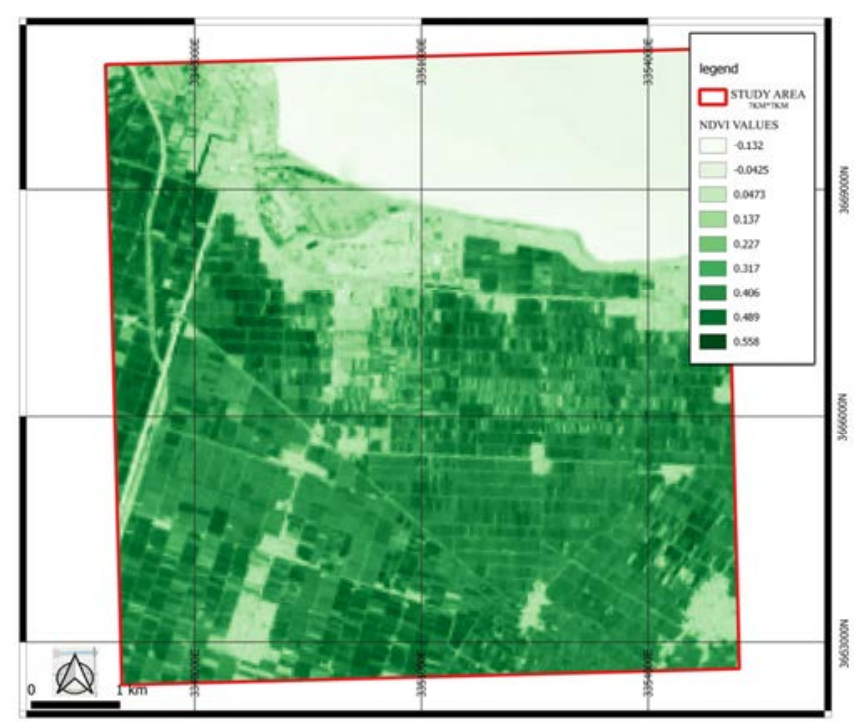

Figure 3: NDVI index, extracted from Landsat 8 image, 8 August 2018.

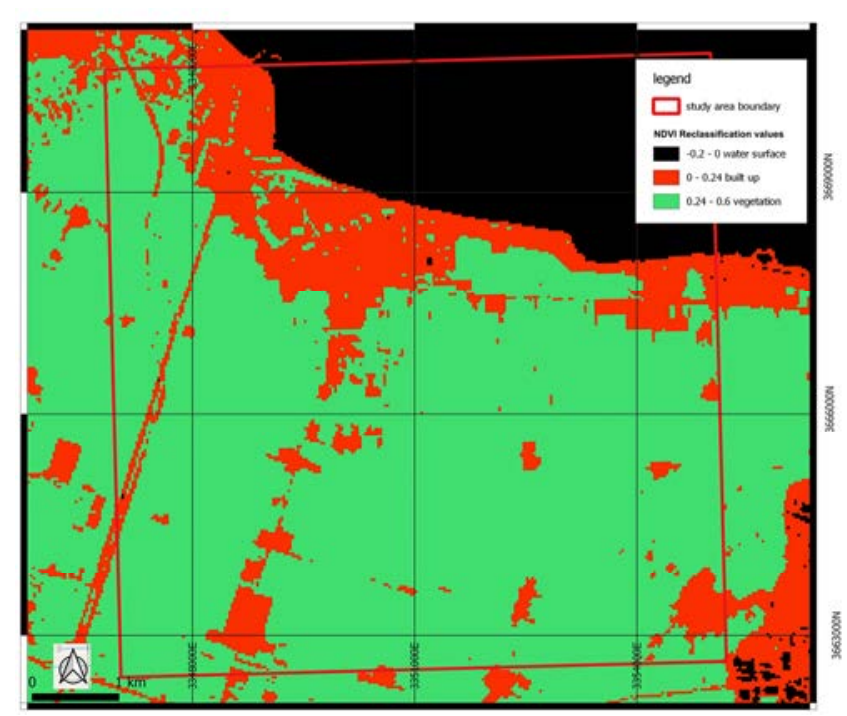

Figure 4: Reclassifying NDVI values to generate built-up regions. 


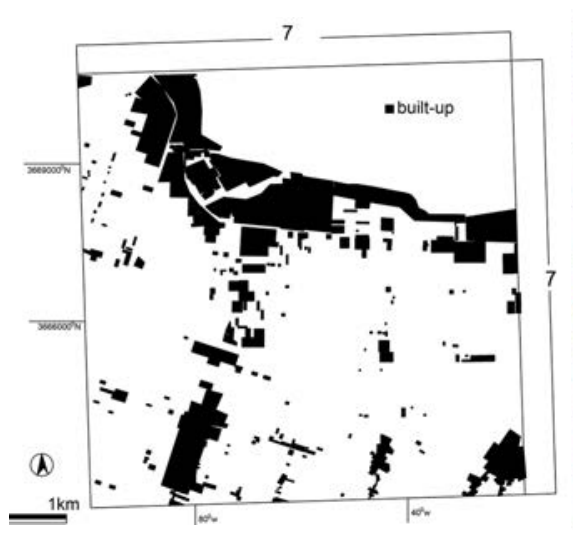

(a)

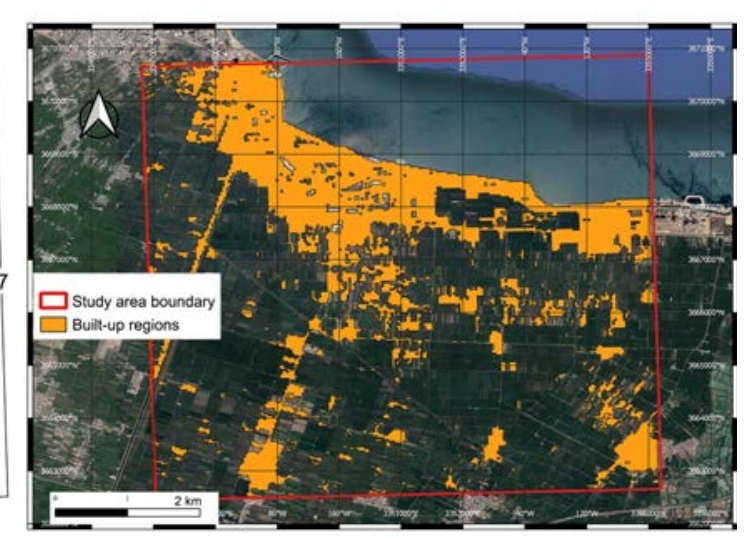

(b)

Figure 5: Built-up areas for the study zone. (a) Hand digitized tracing method; and (b) Built-up vector layer extracted by reclassifying NDVI values.

\subsection{Pollution maps and built-up spatial relation}

Feeding the gaseous dispersion model with the plant inventory design standards, and the emission rates of nitrogen oxides in the area under study derived from (Table 2), resulted in mapping the concentration contours of nitrogen oxides pollutant (shown in Fig. 6(a) and 6(b)). Fig. 6(a) illustrates the contours of the concentrations of $\mathrm{NO}_{\mathrm{X}}$ pollutants that exceed EU standards, and Fig. 6(b) spot the concentrations of $\mathrm{NO}_{\mathrm{X}}$ contours following the legislated EEAA standards. (Fig. 6(c) and 6(d)) shows the safe areas that are not exposed to industrial emitted $\mathrm{NO}_{\mathrm{x}}$ pollutant, following EU standards, and the Environmental Affairs Agency of the Arab Republic of Egypt regulations.

'The Main Features and the capability to simulate turbulent flows of plume dispersion in unprecedented detail is Hard to Predict', making the results of evaluating and site selection validation a great challenge [34]. The different international standards for determining the concentration of nitrogen oxides emissions from the industry, and the variation of the emission coefficient of that pollutant, creates more than one perception for the forecasting strategy. The results identified trends in the transmission of nitrogen oxides $\left(\mathrm{NO}_{\mathrm{X}}\right)$ plumes shows the plumes moving $6.39 \mathrm{~km}$ south-east, $6.91 \mathrm{~km}$ south, and some of the effects are shown traveling towards the west, $6 \mathrm{~km}$ from the center of the industrial complex. These results are generated by plotting the pollution maps of the AERMOD program on QGIS platform (as shown in Fig. 6(a) and 6(b)). Following EU standards, the safe area represents $9.2 \%$ of the total studied habitable land around an industrial facility, while in EEAA regulations; an area of $86.2 \%$ represents the safe area in (Fig. 6(c) and 6(d)). Whereas the strategy detected $\left(0.846 \mathrm{~km}^{2}\right)$ of safe areas following the EU regulations, under the direction of the prevailing wind (Fig. 6(c)).

The spatial analysis done on QGIS platform on extracted built-up zones, spotted a condensed region of built up areas, found to lie in the north-west of the industrial complex. (see Fig. 6(e)), where the projection method of the $\mathrm{NO}_{\mathrm{x}}$ pollutant contours, layered on the vector built-up layer, resulted in the extraction and identification of areas that are highly exposed to industrial emitted pollutants (see Fig. 6(f)). 


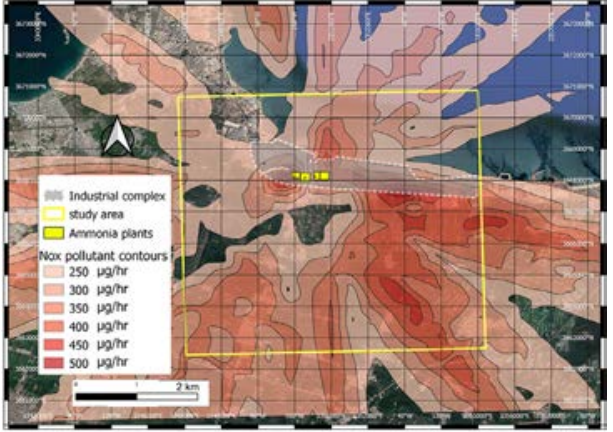

(a)

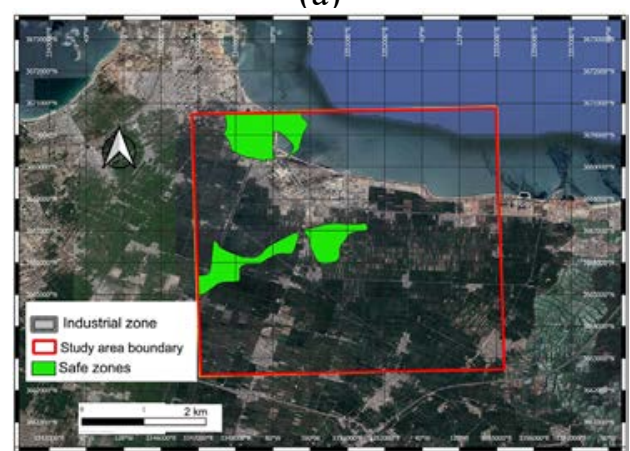

(c)

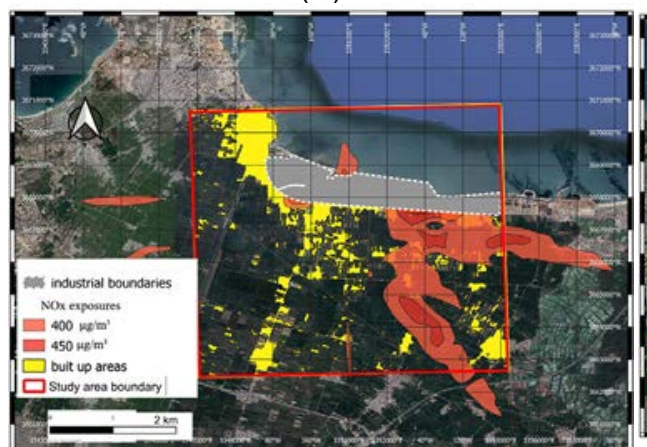

(e)

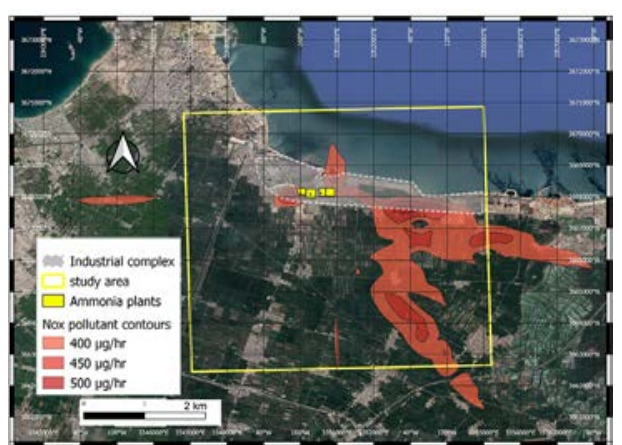

(b)

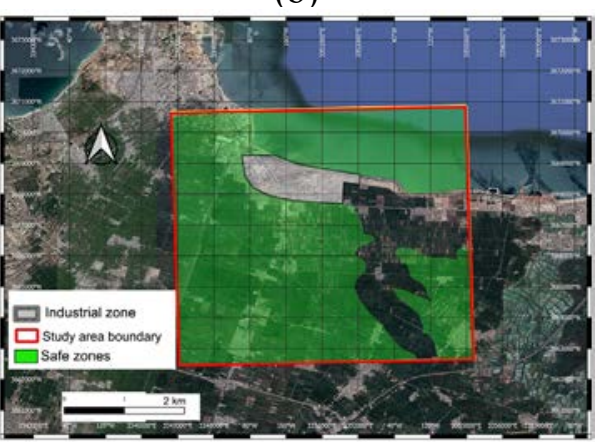

(d)

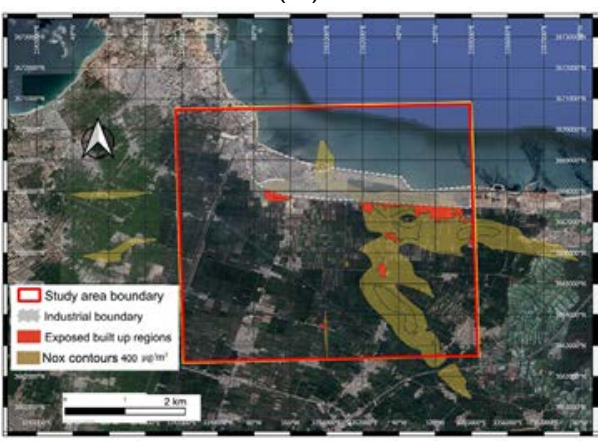

(f)

Figure 6: Spatial analysis of $\mathrm{NO}_{\mathrm{X}}$ pollutant map and built up regions on a total area of $49 \mathrm{~km}^{2}$. (a) EU regulations (above $200 \mu \mathrm{g} / \mathrm{m}^{3}$ for 1 hour exposure); (b) EEAA $\mathrm{NO}_{\mathrm{X}}$ concentrations contours ( $400 \mu \mathrm{g} / \mathrm{m}^{3}$ for 1 hour exposure); (c) Standard EU safe regions (area of $4.162 \mathrm{~km}^{2}$ ); (d) EEAA Safe regions (area of $38.81 \mathrm{~km}^{2}$ ); (e) Built-up regions (yellow) and $\mathrm{NO}_{\mathrm{X}}$ pollution projection contours; and (f) Highly exposed built-up regions $\left(0.918 \mathrm{~km}^{2}\right)$.

\section{CONCLUSIONS AND RECOMMENDATIONS}

Use of dispersion modeling to track regionally transmitted pollution, added semi-accurate numerical data for air pollution in the perimeter of the studied industrial complex. The identification of the built-up areas, using satellite imagery reclassification method, gave 
accurate analytical results of the areas where population activity is concentrated, thus aiding in the creation of a rapid digital cartographic image for those regions.

The study suggests that the application of air modeling simulation and satellite detection process could be used to provide a reliable method of urban decision making in industrial zones. The air modeling techniques used in this paper demonstrated that "It is necessary to consider the safe distance when planning and placing residential plants with industrial spaces in $7 \mathrm{~km}$ from a petrochemical industrial complex".

The possibility of using the NDVI index for vegetation cover can provide maps of the built areas, however, the accuracy of the method is quite limited by the moderate resolution of the data, which means that the contemporaneous tracking of the pollutants extension in the present-day monitoring network, could lead to better results. Further testing of the source, and an increase in the number of observation stations are required to enable the monitoring of pollutant concentrations in the air, in areas adjacent to industrial complexes.

The study recommends the transfer of residential complexes that fall under the contaminated concentrated spots. We also recommend that the methodology followed, should guide the study, and link it to the strategic plan for industrial investment in the region. Given that emission rates inventories are characterized by large uncertainties, using satellite-dispersion modeling method offers a much more cost-effective approach to relocate residential complexes falling under the polluted concentrated spots.

\section{CONFLICT OF INTEREST}

The authors have read and understood the policy of declaration of interests and declare that they have no competing interests. The research received no direct funding from any quarters. This article does not contain any studies with human or animal subjects.

\section{ACKNOWLEDGEMENT}

The authors wish to acknowledge the United States Geological Survey (USGS) for providing the data used for this study.

\section{REFERENCES}

[1] Elias, M.G., Guidelines of Principles and Procedures for Environmental Impact Assessment, Ministry of State for the Environment Egyptian Environmental Affairs Agency, Environment: Cairo, 2009.

[2] EPAP, Industrial Pollution Control, 2010.

www.eeaa.gov.eg/portals/0/eeaaReports/EPAP/Proper/Industerial\%20Policy/Induster ial\%20Pollution $\% 20 \% 20$ policy\%20in\%20Egypt\%20English.pdf. Accessed on: 1 Dec. 2018.

[3] Saidur, R., Energy savings and emission reductions in industrial boilers. Thermal Science, 15(3), pp. 705-719, 2011.

[4] Virginie, M., Dellink, R. \& van Vuuren, D., Organisation for Economic Co-operation and Development (OECD), OECD environment, 2011. www.oecd.org/env/cc/49082173.pdf. Accessed on: 1 Jan. 2019.

[5] EIA, Natural gas and the environment, 2013. http://naturalgas.org/environment/naturalgas/. Accessed on: 31 Dec. 2018.

[6] EPA, Energy efficiency and cost saving opportunities for ammonia and nitrogenous fertilizer production, 2017. www.energystar.gov/sites/default/files/tools/Fertilizer_guide_170418_508.pdf. Accessed on: 19 Jan. 2019. 
[7] Barsi, J.A., Lee, K., Kvaran, G., Markham, B.L. \& Pedelty, J.A., The spectral response of the Landsat-8 operational land imager. Remote Sensing, 6(10), pp. 10232-10251, 2014.

[8] Lo, C.P., Land use mapping of Hong Kong from Landsat images: An evaluation. International Journal of Remote Sensing, 2(3), pp. 231-252, 1981.

[9] atlasofurbanexpansion, Lincoln Institute of Land Policy, 2019. www.atlasofurbanexpansion.org/cities/view/Alexandria. Accessed on: 20 Feb. 2019.

[10] Alexfert, 2013. www.alexfert.com/new/. Accessed on 10 Dec. 2018.

[11] BAT, Best available techniques for the manufacture of large volume inorganic chemicals: Ammonia, acids and fertilisers. European Commission, 2007. http://eippcb.jrc.ec.europa.eu/reference/BREF/lvic_aaf.pdf.

[12] Arizona Department of Environmental Quality (ADEQ), Air Dispersion Modeling Guidelines for Arizona Air Quality Permits, Air Quality, Environmental Quality: Phoenix, Arizona, 2015.

[13] Rawlings, G.D. \& Reznik, R.B., Source assessment: Synthetic ammonia production, Monsanto Research Corp., Dayton, Ohio, 1977. https://nepis.epa.gov/Exe/ ZyPURL.cgi?Dockey=91016QUZ.txt. Accessed on: 29 Jan. 2019.

[14] EPA, 2017. www3.epa.gov/ttn/chief/ap42/c00s00.pdf. Accessed on: 6 Feb. 2019.

USEPA, EPA-453/R-94-023, Alternate control techniques document: $\mathrm{NO}_{\mathrm{X}}$ emissions from utility boilers, 1998. www3.epa.gov/ttn/chief/old/ap42/ch01/s04/final/ c01s04 jul1998.pdf. Accessed on: 20 Jan. 2019.

[15] EPA, 2017. www3.epa.gov/ttn/chief/ap42/c00s00.pdf. Accessed on: 20 Dec. 2018.

[16] U.S. Department of Energy, Energy efficiency and renewable energy, 2014. www.energy.gov/sites/prod/files/2014/05/f15/tech_brief_true_cost.pdf. Accessed on: 1 Mar. 2019.

[17] EFMA, Best available techniques for pollution prevention and control in the European fertilizer industry. Belgium, 2000. www.ocinitrogen.com/Media\%20Library/ Ammonia\%20process\%20-\%20BAT\%20Production\%20of\%20ammonia\%20(2000) \%20-\%20Brochure.pdf. Accessed on: 15 Jun. 2019.

[18] Larsen, J., Michel, M. \& Zschommler (Uhde), J., Large-scale hydrogen plants. Uhde and UOP's experience, New Orleans, 2003.

[19] Michel, M., Design and engineering experience with large. Oil Gas European Magazine, 30(2), 2004.

[20] Kareish, S.E., Petrochemical industry and its development. Oil and Arab Cooperation, 39(146), p. 53, 2013.

[21] Egyptian Environmental Affairs Agency, Egyptian Pollution Abatement Project, Case Summary Abuqir fertilizers company, 2019.

[22] Alborsa. S.H., 2015. https://alborsanews.com/2015/09/22/742993. Accessed on: 12 Nov. 2018.

[23] Chen, X.-L., Zhao, H.-M., Li, P.-X. \& Yin, Z.-Y., Remote sensing image-based analysis of the relationship between urban heat island and land use/cover changes. Remote Sensing of Environment, 104(2), pp. 133-146, 2006.

[24] Nouri, H., Beecham, S., Anderson, S. \& Nagler, P., High spatial resolution WorldView-2 imagery for mapping NDVI and its relationship to temporal urban landscape. Remote Sensing, 6(1), pp. 580-602, 2014.

[25] Matthiasa, B. \& Martin, H., Mapping imperviousness using NDVI and linear spectral unmixing of ASTER data in the Cologne-Bonn region. Proceedings of the SPIE 10th International Symposium on Remote Sensing, Barcelona, Spain, 2003. 
[26] Malik, M.S., Shukla, J.P. \& Mishra, S. Relationship of LST, NDBI and NDVI using Landsat-8 data in Kandaihimmat Watershed, Hoshangabad, India. Indian Journal of Geo Marine Science, 48(1), pp. 25-31, 2019.

[27] QGIS, QGIS official website, 2018. www.qgis.org/en/site/. Accessed on: 27 Nov. 2018.

[28] Vermote, E., Justice, C., Claverie, M. \& Franch, B., Preliminary analysis of the performance of the Landsat 8/OLI land surface reflectance product, 2016.

[29] WorleyParsons Komex, Environmental impact assessment (EIA for a proposed methanol facility in Damietta Port. NTS. Damietta). Resources \& Energy, Worley Parsons Komex, 2006.

[30] PROGRAM META, Evaluation and Future Development of the EIA System in Egypt, Cairo: Manchester University EIA Centre, World Bank (Middle East and North Africa Region) and the METAP, Rural Development, Water and Environment Department, 2000.

[31] EEA, Air Quality in Europe, Luxembourg: European Environment Agency, 2017.

[32] EEAA, Ministry of State for Environmental Affairs, Egyptian Environmental Affairs Agency, EEAA, 2010.

[33] Hertwig, D., On Aspects of Large-Eddy Simulation Validation for Near-Surface Atmospheric Flows, Hamburg, 2013. 